UDC 811.111'367.335.2

https://doi.org/10.18485/bells.2018.10.5

\author{
Vladan Pavlović* \\ University of Niš \\ Faculty of Philosophy \\ Niš, Serbia
}

\title{
ON THE BLURRED BOUNDARIES BETWEEN SUPERORDINATE AND SUBORDINATE CLAUSES IN ENGLISH ${ }^{1}$
}

\begin{abstract}
The paper addresses superordinate and subordinate clauses in English. It focuses on how blurred the distinction between the two categories becomes when syntactic criteria are paired with discourse ones - the structures that are syntactically superordinate may turn out to be "discourse subordinate", and vice versa. More generally, the paper aims to show that the various aspects of linguistic analysis, in this case primarily the syntactic and discourse ones, are tightly intertwined, and that viewing syntactic structures in terms of their discourse functions may help us perceive the gradient and fuzzy nature of the boundaries of linguistic categories, and point to their gradient contribution to overall discourse progress.
\end{abstract}

Key words: superordinate clauses, subordinate clauses, syntax, discourse, complements, adjuncts, gradience, intersubjectivity.

E-mail address: vladanp2@gmail.com

1 This is a revised version of the paper presented at Third International Conference on Science and Contemporary University, held at the Faculty of Philosophy, University of Niš, Serbia, in November 2013, and published as Pavlović 2014. 


\section{Introduction}

The paper deals with what are traditionally taken to be superordinate (matrix) and subordinate (complement and adjunct) clauses. It has two aims. The first is to show that the terms superordinate and subordinate might not be appropriate enough in the designation of different types of clauses, as structures that are syntactically superordinate may be "discourse subordinate", while structures that are syntactically subordinate (such as complement clauses) may be "discourse superordinate", but need not be (as in the case of adjunct clauses). It does so on the basis of Langacker 2008, Verhagen 2005 and Pavlović 2014, all of whom address the difference between (finite) complement and adjunct clauses, both of which are traditionally taken to be subordinate clauses, and their relation to superordinate clauses, from the perspective of interplay between syntax and discourse. The second aim, not dealt with in Pavlović 2014, is to build on such insights by showing that viewing syntactic structures in terms of their discourse functions, i.e. viewing the syntactic and discourse aspects as being tightly intertwined, may help us perceive the gradient and fuzzy nature of the boundaries of the relevant linguistic categories.

In this paper, complement clauses will be taken to mean all the (syntactically subordinate) clauses functioning as the direct object, indirect object, retained object, subject complement, object complement, complement of the noun, complement of the adjective, and restrictive relative clauses. Adjunct clauses will be taken to mean all the (syntactically subordinate) clauses functioning as the adverbial modifier, sentence modifier and non-restrictive relative clauses (for clause types see Quirk et al., 1985: 1047-1076 et passim, Huddleston and Pullum, 2002: 853-945 et passim).

\section{Theoretical background}

This part of the paper will first address the relevant works of Langacker and Verhagen, two authors who come from the fields of Functional and Cognitive Linguistics, respectively. Then it will address the concept of gradience (and the related concept of multiple analysis) in grammatical categories.

Langacker, a well-known representative of Cognitive Linguistics in general (and Cognitive Grammar in particular), presents two quite 
different views of the discourse role of complementation structures in his monographs from different periods. Namely, he first says that the profile ${ }^{2}$ of a complement clause is overridden by that of the superordinate clause (for example, a sentence such as I know she left designates the process of knowing, not of leaving) (Langacker 1991: 436 et passim), which implies that it is the superordinate, rather than the complement clause, that is more discourse-prominent. However, in his later books (such as Langacker 2008: 418-419), he puts forward the view that, from the discourse perspective, the content presented in subordinate clauses is often more important, and provides the following short discourse as an example: There's something [you simply have to know]. It seems [that Gerald's trophy wife is really a transsexual]. I suppose [they'll get a divorce]. I am telling you because [he'll need a good lawyer]. In other words, if one were to rely on the syntactically superordinate clauses only (There's something, It seems, I suppose, I am telling you), one would realize that the discourse hardly makes any progress. On the other hand, if one relied on the dependent (syntactically subordinate) clauses, one would get what could count as a relatively coherent discourse: You simply have to know - Gerald's trophy wife is really a transsexual. They'll get a divorce. He'll need a good lawyer. In that sense, Langacker concludes that this questions whether the clauses traditionally labelled as subordinate actually deserve that label. Namely, he adds, when it comes to conveying essential content, it is often the so-called subordinate clause that plays the leading role. Conversely, it is common for a superordinate clause to have a secondary function, such as indicating the status of that content (It seems, I suppose, etc.) or managing the discourse interaction (I am telling you because...).

Verhagen, a functional-cognitive linguist belonging to the European branch of Cognitive Linguistics (Nuyts 2005: 546), in Verhagen 2005, starts from the presented theoretical perspectives and extends them to written discourse. In this respect, he also introduces the concept of intersubjectivity, which is also quite important for the purposes of this paper.

Namely, he says that language use is intimately tied to the fundamental human ability to coordinate cognitively with others (ibid., p. 8). That cognitive coordination for the speaker / writer means an attempt to influence somebody else's thoughts, attitudes and immediate behaviour, whereas for the addressee it means finding out what kind of influence it is that the speaker / writer is trying to exert and deciding whether

2 For this author's definition of the concept of profile, see ibid., 66-70 et passim. 
to go with it or not (ibid., p. 10). The default condition for ordinary expressions is that they provide an argument for some conclusion, and this argumentative orientation is constant in the function of the expression, while its information value is more variable (ibid.). In this sense, this author claims, ordinary linguistic communication is basically argumentative, not primarily informative (ibid., 22/23), and human language is fundamentally a matter of regulating and assessing others, of mutual influencing, not of information exchange; in addition, grammatical elements and syntactic constructions in general, have systematic, conventional functions in the dimension of intersubjective coordination (ibid., p. 9).

To exemplify this, Verhagen gives the following example (among others): There are seats in this room. But they are uncomfortable. Namely, the second sentence here (But they are uncomfortable) shows that the first one (There are seats in this room) induces an addressee to make positive inferences about the degree of comfort of the seats, which, in turn, can be proved if the first sentence were followed by either of the two following ones: ?And moreover, they are uncomfortable. ?But they are comfortable. In this sense, Verhagen claims that this is an operation in dimension $S$ (i.e. the subjective dimension) of the construal configuration.

Diagram 1 below shows what Verhagen considers to be the construal configuration and its basic elements:

Diagram 1: The construal configuration and its basic elements (Verhagen 2005: 7)

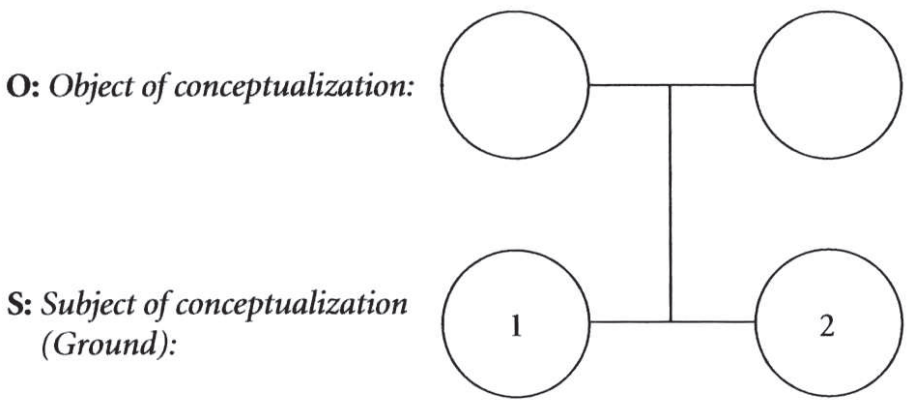


Even when an actual speaker / writer is absent, an addressee (numbered 2 in the diagram above) takes a linguistic utterance as having been intentionally produced as an instrument of communication by another human being (with the same basic cognitive capacities as the addressee) and thus always engages in cognitive coordination with another subject of conceptualization (numbered 1 in the diagram above). Along the same lines, even when the addressee is absent, a speaker / writer assumes that their utterance is in principle interpretable by somebody else sharing the knowledge of certain conventions. It is in this sense, as already stated above, that language use is intimately tied to the fundamental human ability to coordinate cognitively with others (ibid, p. 7/8). That is what the "S-level" (at which there are two circles representing two subjects of cognitive coordination in the lower part of the diagram above) refers to. On the other hand, the "O-level" refers to an object of conceptualization regarding which the speaker / writer and the addressee(s) actually cognitively coordinate.

It can happen that certain utterances pertain primarily to the O-level, as in a sentence such as John owns a horse, whereas other utterances may focus entirely on the dimension of cognitive coordination between / among the subjects of conceptualization, i.e. on the S-level, as when people say Hi, Sorry, Hey, or use other phatic expressions (in Malinowski's well-known terms). The former case is represented in Diagram 2 below (in which the S-level, as the less important one, is depicted by a dotted line), whereas the latter case can be graphically represented as in Diagram 3 below, in which case it is the O-level, as the one that plays a lesser role in such utterance types, that is shown by a dotted line.

Diagram 2: The construal configuration in maximally "objective" expressions (e.g. John owns a horse) (Verhagen 2005: 17)

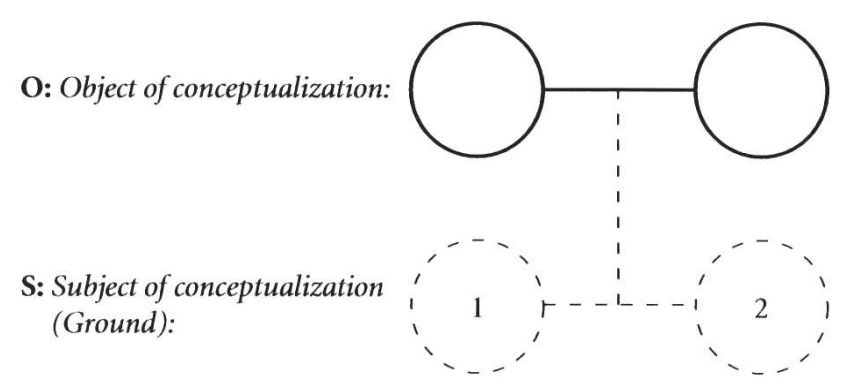


Diagram 3: The construal configuration in maximally "subjective" expressions (e.g. Hi, Sorry, Hey) (Verhagen 2005: 18)

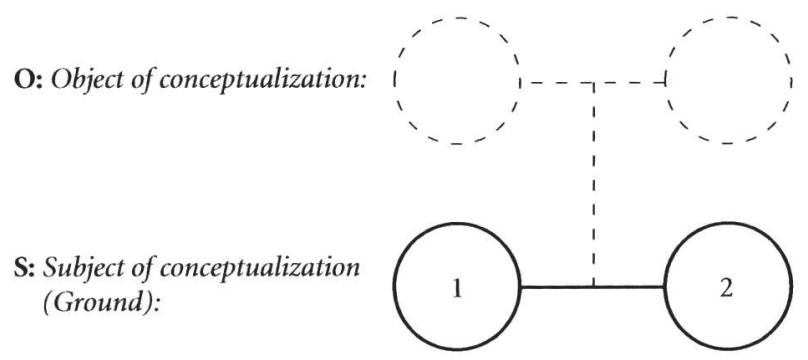

We will now show how the notions of cognitive coordination, the Slevel and the O-level, are linked to the topic of this paper.

Namely, according to Verhagen, the primary function of superordinate (also referred to as complement-taking / CT) clauses of the complementation construction is at the S-level - they operate in the domain of intersubjective coordination, they provide specifications of perspectives rather than descriptions of events / situations (e.g. I believe..., He thinks...), and they invite an addressee to identify with a particular perspective on an object of conceptualization presented in the embedded clause (ibid., p. 79).

Most importantly for the purposes of this paper, such clauses are taken not to present the main line of discourse. Namely, a CT clause is said to specify how to engage in cognitive coordination with another subject of conceptualization, but on its own it does not constitute a complete, relevant contribution to a discourse.

In this sense, complementation constructions are not structural devices to present one objectively construed event as subordinate to another, but devices to invite an addressee to consider an object of conceptualization (presented in a complement clause) from a particular perspective in a particular way (as specified in the superordinate clause / CT clause); they are directly and primarily related to mutual management and assessment (ibid., p. 215). Along the same lines, complementation constructions instruct the addressee of an utterance to coordinate cognitively, in a way specified by the superordinate clause, with another object of conceptualization in construing the object of conceptualization (represented by the superordinate clause) and not that of representing an object of conceptualization (ibid., p. 109). In addition, they can be viewed as general grammaticalized expressions for intersubjective coordination or as a form of grammaticalization of a 
dimension of discourse structure that is orthogonal to its informational content, i.e. they pertain to intersubjective coordination of cognitive systems (ibid., 97). This cognitive coordination can be direct, as when somebody says I promise that..., where the argumentative strength of the first-person, present-tense utterance is maximal; however, in the example such as John promised that..., the argumentative strength of the thirdperson, past-tense utterance is weaker, so that the cognitive coordination between author and addressee can be considered to be more indirect. On the other hand, with complement clauses (as opposed to superordinate / CT clauses), the discourse develops at the O-level.

In addition, the degree of integration into a superordinate clause is higher for a complement than an adjunct clause. In other words, an adjunct clause is more loosely connected to its superordinate clause, so that both the superordinate and the adjunct clause are taken to be separate discourse segments instead of specifying another dimension of a single segment (ibid., p. 150 et passim).

The following observations by Verhagen (2005: 100) are also important for the purposes of this paper. He says that the SVDO (subject / predicator / direct object) is too high a level of abstraction for a proper characterization of complementation constructions, i.e. the constructions consisting of a superordinate and a subordinate complement clause. In other words, whereas it is indeed plausible to analyse a (syntactically simple) sentence such as John owns a house as consisting of the given functional elements, the same cannot and should not be applied to a sentence such as $\underline{I} \underline{k n o w}$ that John owns a house, which is also typically analysed functionally as $S V D O$.

In this sense, Verhagen insists that using simplex clauses (such as John owns a house) as the structural model for an analysis of complementation constructions (as in I know that John owns a house) implies imposing the structure of an object of conceptualization on those constructions, which, in turn, obscures the fact that such syntactically complex constructions serve to link the intersubjective and objective dimensions of linguistic communication. So, whereas simplex clauses are primarily related to an object of conceptualization, the latter type of sentences does that as well (in the complement clause), but also presents an addressee as coordinating cognitively with an object of conceptualization (in the superordinate clause). In other words, the primary function of superordinate clauses of complementation constructions is located at the S-level. They provide 
specifications of perspectives rather than descriptions of events or situations, and the grammatical roles of subject, object, and predicate from simplex clauses have no straightforward application in these constructions, which have a function sui generis (ibid, p. 26, 27).

To try to provide evidence for this, Verhagen gives, among others, the following examples. Firstly, he says that complement clauses can appear in environments in which a noun phrase or a pronoun is impossible - compare He was afraid that he was not going to make it and "He was afraid defeat; Experts warned that the profit would turn out to be lower and "Experts warned a lower profit / *Experts warned this (ibid, p. 82). In addition, one might add, prototypical transitive verbs (e.g. make, build, give) do not take complement clauses (compare: He made a mess and *He made that she be there on time). Moreover, superordinate clauses can behave like parentheticals (parts of sentences that can be placed in various positions in a sentence) - compare: I'm not sure how he managed to do that and How he managed to do that, I'm not sure.

As indicated above, we will now briefly focus on the notions of gradience and multiple analysis as they are also important for the purposes of this paper.

Grammar is to some extent an indeterminate system, in the sense that linguistic categories, structures and levels often do not have neat boundaries (Quirk et al., 1985: 90). A number of linguists (typically those working outside the field of generative grammar ${ }^{3}$ ) have thus emphasized that various linguistic disciplines and levels of analysis are tightly intertwined, that the nature of the structure of language is essentially gradient, and that positing sharp dichotomies in linguistics (including those between syntax and semantics, and we would add, syntax and discourse) can often prove misleading (cf. Bugarski 1969a, Langacker 1987). Verhagen's analysis presented above of how syntactic forms such as main and subordinate clauses (complement and adjunct clauses) contribute to cognitive coordination appears to corroborate such a standpoint. In addition, authors relying on the

3 Gradience as a term is also used in generative grammar but in a different sense. Namely, it is used to refer to various levels of grammatical correctness of various examples (various syntactic structures are seen as not necessarily either completely grammatical or completely ungrammatical, but also as somewhere in-between - perform the task / ?"perform leisure / "perform compel ). As opposed to generative grammarians using the given term in such a sense (Chomsky 1961, Fanselow et al. 2006, Keller 2000), the authors cited above explore a different sort of gradience, one in which all the examples analysed are generally fully grammatically correct. 
concept of gradience in their work have stressed that instead of analysing carefully selected (sometimes even carefully constructed) examples that aim to present the theoretically postulated poles of a linguistic phenomenon in their purest realizations, a linguistic analysis should strive to broadly encompass broad continua that can be found in-between these poles and that can be approached from the viewpoint of various linguistic disciplines. Such an approach would enable researchers to posit both more central and more peripheral examples of various linguistic categories. In other words, such an approach would enable linguists to show that a particular category can be taken to have the linguistically relevant traits pertaining to that category in different degrees and that linguistic categories need not have clear-cut boundaries. In addition, such a broadly encompassing approach would bring into focus the important and yet possibly insufficiently clear rules of language structuring whose functioning and variability can be seen more easily only through such approaches (cf. Bugarski 1969a).

In addition to the listed sources, the concept of gradience in grammatical categories has also been dealt with in Aarts et al. 2004, Aarts, 2007, Bugarski 1968, 1969b, Pavlović 2017, Piper 2002a, 2002b, 2002c, and Radovanović 2008, 2007a, 2007b, inter alia.

Another kind of indeterminacy that is important for the purposes of this paper is multiple analysis. It essentially means proposing two or more different analyses of the same linguistic phenomenon (such as sentence structure). Such alternative analyses may be needed on the grounds that some of the generalizations that have to be made require one analysis, while others require another. In addition, a gradient may be established between the alternative analyses, so that specific examples may vary in the degree to which one analysis is more appropriate than another (Quirk et al., 1985: 90-91).

In view of the above, it will be one of our aims in this paper to give additional theoretical credence to analysing one and the same group of syntactic structures making up a discourse as discourse superordinate or subordinate, and syntax superordinate or subordinate (with various combinations thereof). We will try to establish a gradient of such groups of examples on a cline pertaining to the contribution of such structures to overall discourse progress, starting with those that significantly contribute to it, and ending with those that contribute the least. 


\section{The corpus and the method}

The corpus of this paper consists of written texts that are stylistically varied. The corpus resources used are as follows:

a) an excerpt from a book of fiction: Baldacci, D. (1999): Saving Faith. New York: Warner Books. p. 140-196;

b) an academic paper: Bencini, G. M. L. / Goldberg, A. (2000). The Contribution of Argument Structure Constructions to Sentence Meaning. Journal of Memory and Language, 43, 640-651;

c) select articles from the Inc. online magazine (available at: https://www.inc.com/).

Approximately 100 pages of text were sampled from the given resources.

For the analysis of the excerpted materials, this paper first relies on the framework adopted in Verhagen 2005: 94-97 and 149-151. Namely, the clauses commonly analysed as subordinate (i.e. complement and adjunct clauses) were first separated from the superordinate clauses. Then the contribution of both types of subordinate clauses, on the one hand, and of the superordinate clauses, on the other hand, was analysed with respect to their role in providing coherence and the "overall progress" of the discourse. Naturally, there were always some parts of the excerpted texts that contained no complement or adjunct clauses at all (i.e. those where there were no syntactically complex / compound-complex sentences), but that consisted only of what can be taken to be syntactically independent (i.e. simplex) clauses. As such clauses were also a part of the examined texts, their contribution to the coherence and the overall progress of the discourse was also taken into consideration.

As indicated in Section 2, once the overall contribution of various types of clauses to overall discourse progress has been established, the paper then presents a possible gradient of such groups of examples on a cline pertaining to the contribution of such structures to overall discourse progress, starting with those that significantly contribute to it, and ending with those that contribute the least.

\section{Data and discussion}

This part of the paper will analyse a part of the materials listed above and will do so along the lines presented. 
Vladan Pavlović: On the Blurred Boundaries between Superordinate and Subordinate ...

The sample text below is the abstract from Bencini / Goldberg (2000: 640).

What types of linguistic information do people use to construct the meaning of a sentence? Most linguistic theories and psycholinguistic models of sentence comprehension assume that the main determinant of sentence meaning is the verb. This idea was argued explicitly in Healy and Miller (1970). When asked to sort sentences according to their meaning, Healy and Miller found that participants were more likely to sort sentences according to the main verb in the sentence than according to the subject argument. On the basis of these results, the authors concluded that the verb was the main determinant of sentence meaning. In this study we used the same sorting paradigm to explore the possibility that there is another strong influence on sentence interpretation: the configuration of complements (the argument structure construction). Our results showed that participants did produce sorts by construction, despite a well-documented tendency for subjects to sort on the basis of a single dimension, which would favor sorts by verb.

The first part of the analysis carried out consisted of separating complement clauses (presented in the right-hand column of Table 1 below) from the superordinate clauses (presented in the left-hand column of the same table) and exploring how each of them contributes to the coherence and "overall progress" of the discourse. Adjunct clauses were grouped with superordinate clauses. The basic conclusion that can be reached on the basis of the given data is that the given string of syntactically superordinate clauses (sometimes accompanied by adjunct clauses), when viewed from the discourse perspective, can be said to contain practically no semblance of any coherent discourse at all: Most linguistic theories and psycholinguistic models of sentence comprehension assume / When asked to sort sentences according to their meaning, Healy and Miller found / On the basis of these results, the authors concluded / In this study we used the same sorting paradigm to explore the possibility / Our results showed (?).

On the other hand, when the syntactically subordinate (i.e. syntactically dependent) complement clauses alone are taken into account, and when they are viewed from the same perspective, it can be concluded that it is they, rather than the syntactically superordinate ones, that present the basic content of the discourse, and that, generally speaking, it is they that 
constitute a more or less coherent piece of text: the main determinant of sentence meaning is the verb / participants were more likely to sort sentences according to the main verb in the sentence than according to the subject argument / the verb was the main determinant of sentence meaning / there is another strong influence on sentence interpretation: the configuration of complements (the argument structure construction) / participants did produce sorts by construction, despite a well-documented tendency for subjects to sort on the basis of a single dimension, which would favor sorts by verb.

Table 1. The sample text with complement clauses separated from the rest of the text

\begin{tabular}{|c|c|}
\hline $\begin{array}{c}\text { SUPERORDINATE } \\
\text { (AND SUBORDINATE ADJUNCT) } \\
\text { CLAUSES }\end{array}$ & COMPLEMENT CLAUSES \\
\hline $\begin{array}{l}\text { Most linguistic theories and psycholinguistic } \\
\text { models of sentence comprehension assume }\end{array}$ & $\begin{array}{c}\text { (that) the main determinant of sentence } \\
\text { meaning is the verb }\end{array}$ \\
\hline $\begin{array}{l}\text { When asked to sort sentences according to } \\
\text { their meaning, Healy and Miller found }\end{array}$ & $\begin{array}{c}\text { (that) participants were more likely to sort } \\
\text { sentences according to the main verb in } \\
\text { the sentence than according to the subject } \\
\text { argument }\end{array}$ \\
\hline $\begin{array}{c}\text { On the basis of these results, the authors } \\
\text { concluded }\end{array}$ & $\begin{array}{c}\text { (that) the verb was the main determinant } \\
\text { of sentence meaning }\end{array}$ \\
\hline $\begin{array}{l}\text { In this study we used the same sorting } \\
\text { paradigm to explore the possibility }\end{array}$ & $\begin{array}{c}\text { (that) there is another strong influence on } \\
\text { sentence interpretation: the configuration } \\
\text { of complements (the argument structure } \\
\text { construction) }\end{array}$ \\
\hline Our results showed & $\begin{array}{l}\text { (that) participants did produce sorts by } \\
\text { construction, despite a well-documented } \\
\text { tendency for subjects to sort on the basis } \\
\text { of a single dimension, which would favor } \\
\text { sorts by verb. }\end{array}$ \\
\hline
\end{tabular}

Something quite different can be observed when adjunct clauses (rather than complement ones) get separated from the rest of a text. The excerpt below comes from Baldacci (1999: 195): 
Although Faith felt her heart in her throat the entire time, they went through the security gate without incident. As they passed the flight information monitors, Lee spotted their gate. "Down this way." Faith nodded as she noted how the gates were configured here. The departure gate for the San Francisco flight was close enough to easily get to, but far enough away from the Norfolk gate. She hid a smile. Perfect. As they walked along, she looked over at Lee. He had done a lot for her.

As can be seen from Table 2 below, the adjunct clauses are now given in the right-hand column, whereas the remaining part of the text - the superordinate and subordinate clauses, as well as syntactically simple and compound sentences, are presented in the left-hand column of the same table. What can be observed now is that the text in the left-hand column provides the main part of the discourse - that which is (relatively) coherent and indispensable to the overall progress of the discourse: they went through the security gate without incident / Lee spotted their gate / "Down this way." / Faith nodded / The departure gate for the San Francisco flight was close enough to easily get to, but far enough away from the Norfolk gate. She hid a smile. / Perfect. / she looked over at Lee. He had done a lot for her.

On the other hand, the adjunct clauses merely provide additional pieces of information, and their sequence does not constitute any coherent piece of discourse: Although Faith felt her heart in her throat the entire time / As they passed the flight information monitors / as she noted how the gates were configured here / As they walked along (?). 
Table 2. The sample text with adjunct clauses separated from the rest of the text

\begin{tabular}{|c|c|}
\hline $\begin{array}{l}\text { SIMPLEX AND COMPOUND CLAUSES } \\
\text { AND VERBLESS UTTERANCES }\end{array}$ & ADJUNCT CLAUSES \\
\hline $\begin{array}{c}\text { they went through the security gate without } \\
\text { incident }\end{array}$ & $\begin{array}{c}\text { Although Faith felt her heart in her throat } \\
\text { the entire time }\end{array}$ \\
\hline Lee spotted their gate & $\begin{array}{c}\text { As they passed the flight information } \\
\text { monitors }\end{array}$ \\
\hline "Down this way." & \\
\hline Faith nodded & $\begin{array}{c}\text { as she noted how the gates were configured } \\
\text { here }\end{array}$ \\
\hline $\begin{array}{l}\text { The departure gate for the San Francisco } \\
\text { flight was close enough to easily get to, but } \\
\text { far enough away from the Norfolk gate. She } \\
\text { hid a smile. }\end{array}$ & \\
\hline Perfect. & \\
\hline $\begin{array}{l}\text { she looked over at Lee. He had done a lot } \\
\text { for her. }\end{array}$ & As they walked along \\
\hline
\end{tabular}

To summarize, the data above show that there is indeed a considerable distinction between the syntactic and the discourse status of the various types of clauses presented here. They also testify to the importance of relying on Verhagen's notion of intersubjectivity or cognitive coordination, alongside the related notions of the S-level and the O-level, which have helped significantly in shedding light on the above distinctions.

On the one hand, as indicated above, complement clauses can be considered to be more tightly integrated into their superordinate clauses than adjunct ones and to present the main line of discourse - that developing at the O-level. In addition, the primary function of superordinate clauses in the syntactic structures that contain a complement clause can indeed be said to operate at the S-level, i.e. in the domain of intersubjective coordination. They can be taken not to present the main line of discourse (they do not constitute a complete, relevant contribution to it); instead, they specify how one is to engage in cognitive coordination with another subject of conceptualization. 
On the other hand, an adjunct clause can be viewed as more loosely connected to its superordinate clause, so that each of these, both the superordinate and the adjunct clauses, are taken to be separate discourse segments instead of specifying another dimension of a single segment. In addition, the latter (the adjunct clause) can indeed be said to relate to its superordinate clause as a satellite discourse fragment to its nucleus, the nuclei constituting the text's main line. In this sense, the (syntactically) superordinate clauses provide the skeleton of the discourse, determining its overall structure, whereas the (syntactically) subordinate adjunct clauses provide additional pieces of information, and are thus not crucial in the overall progress of a discourse.

Using the distinctions thus established, we will now try to posit a gradient relating to how much each of the given clause types contributes to overall discourse progress. To start with, it is simplex (syntactically simple and independent) clauses, clauses comprising compound sentences, and (subordinate) complement clauses that contribute most to discourse progress. On the other hand, it is superordinate clauses appearing with complement clauses and (subordinate) adjunct clauses that contribute to a somewhat lesser extent, and are thus to be located towards the end of the gradient. This once again testifies to how blurred the boundary is between what is commonly referred to as a superordinate and subordinate clause when the interplay of syntactic and discourse considerations is considered, and to the gradient nature of the contribution of different types of clauses to overall discourse progress.

In addition, the distinction between superordinate and subordinate clauses, as well as the various distinctions among the subordinate clauses themselves (the nominal, the adjectival / relative and the adverbial ones), may be quite useful and quite appropriate syntactically speaking. However, in view of the discourse considerations presented above, these distinctions may be misleading, because, as we can see, structures that are syntactically superordinate may be discourse subordinate, while structures that are syntactically subordinate (such as complement clauses) may be discourse superordinate, but need not be (as in the case of adjunct clauses). In short, the relation between the syntactically superordinate and subordinate clauses (and among the types of subordinate clauses themselves), in cases where that status is viewed against the background of the discourse they appear in, need not necessarily reflect their discourse status. This also justifies the reliance on multiple analysis in analysing language phenomena. 


\section{Concluding remarks}

This paper has dealt with what it actually means to say that a clause is subordinate or superordinate and concluded that, from the perspective of interplay between syntax and discourse, the boundaries between the two are blurred, and that their contribution to overall discourse progress can be construed as a gradient.

There are several directions in which such an analysis can be elaborated. Firstly, it can be performed on a much broader corpus in English than the one covered here to check how tenable the conclusions drawn here are. For example, the paper considers adjunct clauses as those that do not contribute much to overall discourse progress. Still, there is evidence available in the literature that there are cases when, contrary to the views put forward in this paper, for example, non-restrictive relative clauses, as a type of adjunct clauses can actually be taken to present the speaker's central communicative message (see Živković, 2016). In addition, there are cases where the semantics of the main verb crucially affects the meaning of the main verb in the complement clause (compare for example Imagine that somebody gave you \$1,000 and Somebody gave you \$1,000, It would appear that this question is impossible to answer and This question is impossible to answer). In other words, the failure to consider the broader sentential context in which a specific type of clause appears may possibly lead to mistaken conclusions about the importance of various clause types in discourse progress. What is more, the paper has addressed only finite subordinate clauses, rather than not finite ones as well. In this sense, more research is clearly needed so as to establish more tenable conclusions and preferably rule-governed generalizations in this area. Secondly, it may be worthwhile examining other languages along the lines presented in this paper so as to possibly arrive at some typologically-relevant conclusions. And thirdly, the paper also has pedagogical implications. Namely, the standpoints presented above are typically not dealt with in syntax classes, and should therefore (at least briefly) be presented to students, as such an approach could enhance their knowledge of the given phenomena and make them more aware of the complex relations that can be found when the same linguistic material is viewed from the perspective of two (or more) different linguistic disciplines. 


\section{References}

Aarts, B. (2007). Syntactic Gradience - The Nature of Grammatical Indeterminacy. Oxford: OUP.

Aarts, B. et al. (eds.) (2004). Fuzzy Grammar - A Reader. Oxford: OUP.

Bugarski, R. (1968). On the interrelatedness of grammar and lexis in the structure of English. Lingua, 19:3, 233-263.

Bugarski, R. (1969a). Predlozi over, under, above, below $i$ beneath $u$ savremenom engleskom jeziku. Beograd: Filološki fakultet.

Bugarski, R. (1969b). Symmetry and asymmetry in prepositional systems. Zbornik radova povodom četrdesetogodišnjice osnivanja Katedre za engleski jezik $i$ književnost. Beograd: Filološki fakultet, 57-69.

Chomsky, N. (1961). Some Methodological Remarks on Generative Grammar, Word, 17, 219-239.

Fanselow, G. et al. (eds.) (2006). Gradience in Grammar: Generative Perspectives. Oxford: OUP.

Huddleston, R. and G. K. Pullum (2002). The Cambridge Grammar of the English Language. Cambridge: CUP.

Keller, F. (2000). Gradience in Grammar: Experimental and Computational Aspects of Degrees of Grammaticality. PhD Thesis, University of Edinburgh.

Langacker, R. (1987): Foundations of Cognitive Grammar, Vol. I: Theoretical Prerequisites. Stanford: Stanford University Press.

Langacker, R. (1991). Foundations of Cognitive Grammar, Vol. II: Descriptive Application. Stanford: Stanford University Press.

Langacker, R. (2008). Cognitive Grammar - A Basic Introduction. New York: OUP Inc.

Nuyts, J. (2007). Cognitive Linguistics and Functional Linguistics. In: D. Geererts and H. Cuyckens, eds. Handbook of Cognitive Linguistics. Oxford: OUP. p. 543-565.

Pavlović, V. (2014). On Complement and Adjunct Clauses in English from Discourse Perspective. Jezik, književnost i kultura - Tematski zbornik radova [sa trećeg Međunarodnog naučnog skupa Nauka i savremeni univerzitet, Niš, 2013]. Niš: Filozofski fakultet. Tom 4. 414-425.

Pavlović, V. (2017). Sintaksička gradijentnost u engleskom jeziku. Niš: Filozofski fakultet.

Piper, P. (2002a). O principu graduelnosti u leksikografskom opisu. U: Deskriptivna leksikografija standardnog jezika i njene teorijske osnove 
(Međunarodni naučni skup o leksikografiji leksikologiji), Novi Sad / Beograd: SANU, Matica Srpska, Institut za srpski jezik SANU. 133-139.

Piper, P. (2002b). Gramatika granice. Južnoslovenski filolog, 64. Beograd: Institut za srpski jezik SANU. 307-322.

Piper, P. (2002c). Stepenovanje u gramatici i rečniku. Zbornik Matice srpske za slavistiku, Novi Sad: Matica srpska. 59-78.

Quirk, R. et al. (1985). A Comprehensive Grammar of the English Language. London and New York: Longman.

Radovanović, M. (2007a). Pregled osnovnih pitanja vezanih za pojam graduelnosti u lingvistici. Zbornik Matice srpske za filologiju i lingvistiku, 50. Novi Sad: Matica srpska. 747-757.

Radovanović, M. (2007b). Pojam graduelnosti u lingvistici, logici i u nauci uopšte. Zbornik Matice srpske za slavistiku, Novi Sad: Matica srpska. 337-350.

Radovanović, M. (2008). Fazi logika u lingvistici: Temeljni pojmovnik i sistematizacija. U: M. Radovanović, P. Piper (ur.), Semantička proučavanja srpskog jezika. Beograd: SANU, 11-44.

Thompson, S. (2002). 'Object Complements' and Conversation: Towards a Realistic Account. Studies in Language 26. 125-164.

Verhagen, A. (2005). Constructions of Intersubjectivity: Discourse, Syntax and Cognition. Oxford: OUP.

Wellander, E. (1947). Riktig svenska. Stockholm: Almqvist \& Wiksell.

Živković, E. (2016). The At-Issue Status of Appositive Relative Clauses; Evidence for a Discourse-Based Apporach. (Unpublished Master Thesis, Pompeu Fabra University, Barcelona, Spain).

Received: 6 October 2017

Accepted for publication: 31 January 2018 
Vladan Pavlović: On the Blurred Boundaries between Superordinate and Subordinate ...

Владан Павловић

\section{О НЕЈАСНИМ ГРАНИЦАМА ИЗМЕБУ СУПЕРОРДИНИРАНИХ И СУБОРДИНИРАНИХ КЛАУЗА У ЕНГЛЕСКОМ ЈЕЗИКУ}

\section{Сажетак}

Рад се бави суперординираним и субординираним клаузама у енглеском језику. Посебно се разматра то колико граница између два дата типа клауза постаје нејасна када се синтаксички критеријуми укрсте са погледом на дата два типа клауза из дискурсног угла. Тако се неретко испоставља да структуре које су синтаксички суперординиране могу заправо бити дискурсно субординиране, и обратно. Шире посматрано, рад настоји да покаже да различити аспекти лингвистичке анализе, у овом случају посебно синтаксички и дискурсни аспекти, јесу тесно испреплетени, као и да посматрање синтаксичких структура у светлу њихових дискурсних функција може помоћи да се боље увиди градијентна природа граница лингвистичких категорија као и њихов градијентан допринос укупном току неког дискурса.

Кључне речи: суперординиране клаузе, субординиране клаузе, синтакса, дискурс, комплементи, адјункти, градијентност, интерсубјективност 